\title{
Essential problems of history of World War II from perspective of Russian and foreign neoliberals
}

\author{
Vladimir Bruz ${ }^{1, *}$, Sergey Vitinev ${ }^{1}$, Anatoly Solodilov ${ }^{1}$ \\ ${ }^{1}$ Moscow Region State University, 24, Very Voloshinoy str., 141014, Mytishi, Russia
}

\begin{abstract}
The paper considers trending matters of the history of World War II based on views of contemporary Russian and foreign representatives of neoliberalism. The present topic is relevant since neoliberalism supporters attempt to reconsider the key events of World War II, which is especially noticeable just before the $75^{\text {th }}$ anniversary of its end. Instead of serious historical research, numerous works of neoliberal authors contain highly ideologically charged representation of the events considered, which usually has anti-Russian trends. The present paper investigates neoliberal judgments and views of Russian and foreign authors on the reasons of World War II, its beginning, the Eastern Front (which in Russia is called the Great Patriotic War) and on the image of the Soviet army. These particular aspects are usually payed special attention and considered from the perspective of the new neoliberal reading. The aim of this paper is to perform the analysis of neoliberal views on some key aspects of World War II. The authors consider the rationale proposed by neoliberals and try to identify the grounds for reconsideration of a number of events of World War II. The key method of analysis performed was the dialectical method. Such specific methods as those of analysis, synthesis, comparative-historical and problematic-chronological methods, methods of actualization, of specific and logical analysis and some other ones were applied as well. As the result of the research conducted, the authors ascertained that in both Russia and foreign countries neoliberal views on important matters of World War II stem from ideology and political interests. In fact, there is the aim pursued to substantiate the responsibility and blame of the Soviet Union for starting the war, inhumanity of soviet regime and barbarity of the Soviet army. To attain this, in the context of informational war that is currently taking place all means are used from distortion of facts to fabrications and outright lies. Such methods are obviously unscientific and have nothing to do with historical research. The political objective of the ideological campaign run is to show Russia, which is the legal successor state of the Soviet Union, as the aggressive country that treats the free liberal world. The proceedings of the present paper may be relevant for historians, political analysts and theorists as well as for those who are engaged in World War II and particularly its Eastern Front.
\end{abstract}

\footnotetext{
${ }^{*}$ Corresponding author: vvb54@yandex.ru
} 


\section{Introduction}

We are seventy-five years away from the end of World War II, and year by year the number of participants and witnesses of those both heroic and tragic events is becoming less. Nevertheless, people commemorate the great Victory. At the state level, celebratory parades and festivals are annually held, care and support for the veterans are provided. As for the personal level, it is family memory. Each of us knows, remembers and honors our relatives who contributed to the Victory having been either in the field or in the rear. Almost each family has memorable photographs, letters, family heirlooms and stories about war to keep and pass to a younger generation. Therefore, all we have the right to be proud of the Great Victory. This is the "tearful holiday" since our people paid a very high price for the Victory. The war affected every family, therefore, the duty of us as of heritors of the Great Victory, is to honor the bright memory of those who gave their lives for us and for our Motherland. There is no longer the Soviet Union that made a decisive contribution to the Victory in World War II, but the memory has remained with people living in the countries that constituted the USSR. This is the common thing about peoples of these countries. Therefore, as President of Russia Vladimir Putin fairly noticed, "it is important to convey to the descendants the memory of the fact that the victory over Nazism was achieved primarily by the Soviet people, that in the field and in the rear representatives of all the republics of the Soviet Union stood shoulder to shoulder with each other during this heroic struggle" [45]. A striking evidence of this fact is the event called Immortal Regiment [14], which has become an international massive civil-patriotic movement intended to preserve the personal memory of the generation of the Great Patriotic War. In 2019, the Immortal Regiment procession took place in 500 cities of 110 countries around the world [34]. In Russia, more than 10 million people were involved [28].

However, some people do not share this attitude. That is the reason why representatives of the neoliberalism stage the main strike on the memory of people, obsessively attempting to rewrite the history of World War II. Such a "new" history does not have place for heroism and dedication, patriotism of the Soviet people, manifested during those severe years. There is no place for everything that is associated with the Soviet, since, according to the neoliberals, the Soviet Government was criminal, therefore this period should be branded and erased from history. The conclusion that during periods of acute confrontation and wars historiography is largely politicized, that was made by the author of the present paper ten years ago, find endorsement in practice [16].

\section{Objective and tasks}

Based on the aforesaid, it seems necessary to carry out an analysis of neoliberal views and assessments on some of the most significant issues of World War II. For these purposes, the essence of these views is to be defined, the argumentation proposed by neoliberalists is to be considered and the neoliberal interpretation of history of the Second World War is to be comprehend.

\section{Methods}

To solve the problems set, such methods as the dialectical method, those of analysis, synthesis, comparative-historical and problematic-chronological methods, methods of actualization, of specific and logical analysis and some other ones were applied. 


\section{Results and discussion}

\subsection{Causes of World War II}

According to one of the founders of modern neoliberalism F.A. Hayek, the reason of the Second World War consisted in the acute irreconcilable ideological struggle between liberalism and totalitarianism (The term "totalitarianism" was first used by Giovanni Amendola in 1923 to critically characterize the regime of B. Mussolini. Subsequently, this term was also used in relation to the regimes of Nazi Germany and the Soviet Union. In 1939, the American researcher Carlton Hayes explained at the first academic symposium dedicated to the nature of totalitarian states that totalitarianism was a phenomenon of bourgeois society and did not work outside of it. Carlton Hayes attributed Mussolini's Italy and Hitler's Germany to totalitarian regimes. Stalin's Soviet Union, in his opinion, was a completely different type of state. The Political Symposium, held in the United States in 1952 , adopted the term totalitarianism as a scientific concept. However, some political scientists believe that totalitarianism is a political metaphor, a cliché, and the meaning of this concept has been constantly changing in order to satisfy the political situation. In the American «Encyclopedia of Social Sciences», 1968, totalitarianism is reasonably called an «unscientific concept». In fact, the term totalitarianism has a quite obvious opportunistic ideological goal to equate the Soviet regime with Nazism. This term does not carry any other scientific, positive meaning) in the context of a single European civilization. This struggle has grown into the military conflict $[7,11]$.

Zita Whalley believes that "when the war (World War II - author's note) started engulfing the whole world, European countries fought an ideological battle between communism and capitalism" [13].

Professor Richard Overy, the English historian, speaks of this war as of "the huge struggle between two dictatorships (Soviet and fascist ones - author's note)" [11].

The ideological nature of the war is evidenced, in particular, by the statements made by representatives of all parties in the House of Commons of the United Kingdom on September 3, 1939, when the war was declared. Thus, the leader of the Liberal Party A. Sinclair said: “... the world shall know that, as the Prime Minister, said the British people are full of stern determination to terminate the rule of Nazis forever and build a world based on justice and freedom" [12].

Neoliberals perceive this war precisely as a defense of traditional liberal values [7, 11], which helped Great Britain to become the country populated by independent, tolerant and noble people [7], from the totalitarian regimes of Germany, Italy and Russia.

The official standpoint of the USA on this issue was voiced by Acting US Secretary S. Welles at a press conference that took place on June 23, 1941. It was declared that for the United States, the principles and doctrines of the communist dictatorship are as intolerant and alien as the principles and doctrines of the Nazi dictatorship. However, according to the US government, any fight against Hitlerism, any uniting of forces opposing Hitlerism, regardless of their origin, would have hastened the end of contemporary German leaders, and thus would have contributed to their own defense and security. Hitler's armies that day were the main threat to the American continent [5].

Harry S. Truman, a member of the Democratic Party and Senator from Missouri and a future president of the United States by June 1941, commented the situation even more straightforwardly and cynically in his interview to the New York Times. He invited the United States to help a losing side. "If we see that Germany is winning we ought to help Russia and if Russia is winning we ought to help Germany, and that way let them kill as many as possible, although I don't want to see Hitler victorious under any circumstances. None of them keep their word" [10]. 
Thus, the United States perceived the Soviet Union as just a temporary ally until the victory over Nazi Germany and its satellites.

As for the economic, political, social and other reasons of World War II, the neoliberal approach considers them in terms of confrontation between liberalism and totalitarianism.

\subsection{Totalitarianism started war against liberalism}

Speculating further on this thesis, they insist on equal responsibility of totalitarian regimes of both Hitler's Germany and the Stalin's Soviet Union for unleashing World War II.

To prove this idea, they usually refer to the non-aggression pact between the Soviet Union and Germany, also known as the Molotov-Ribbentrop Pact, concluded on August 23, 1939 and supplemented by a secret protocol. According to the neoliberals, it was this pact that led to the war.

For instance, Academician of the RAS Y.S. Pivovarov believes that with the MolotovRibbentrop Pact, Stalin launched the Second World War [22].

According to academician A.N. Yakovlev, the architect of "perestroika", "the partition of Poland, according to the secret Ribbentrop-Molotov protocols, was not an unexpected act arising from some contrived geopolitical interests before the start of World War II. Stalin had been planning this action for a long time. In this regard, the following quite consistent question arises: who was especially active in preparing for World War II, planning aggression against Poland?” [44]. Yakovlev deems the answer obvious: “... the policy of the dictator led to war. But Hitler clearly outplayed Stalin. It was only about who will be ahead" [44]. This opinion is shared by other Russian neoliberals [22].

This point of view is also fully shared by the American economist and liberal writer Richard M. Ebeling, who states: "It is fairly clear that Stalin, having helped to start the Second World War through his pact with Hitler, was readying to attack Germany and begin the process of Sovietizing the European continent. Hitler, guided by his own aggressive ambitions, merely beat him to the punch by striking first." [2]

Due to political aspects, this viewpoint has been manifested in some official European documents since recently. For instance, the Resolution of the European Parliament of September 19, 2019 "On the importance of European remembrance for the future of Europe" emphasizes that World War II, the most destructive war in European history, was launched directly due to the notorious Nazi-Soviet non-aggression pact of August 231939 , also known as the Molotov-Ribbentrop Pact, and its secret protocols, according to which two totalitarian regimes, pursuing the goal to conquer the world, divided Europe into two zones of influence [3]. Thus, the USSR was assigned the same responsibility as Nazi Germany for unleashing World War II.

On April 9, 2015, the Verkhovna Rada of Ukraine adopted a number of laws on "urgent decommunization" (Laws of «urgent decommunization», adopted by the Verkhovna Rada on April 9, 2015: «On the legal status and respect for the memory of the participants in the struggle for independence of Ukraine in the XX century», «On the perpetuation of the victory over Nazism in World War II 1939-1945», «On the condemnation of the communist and national-socialist (Nazi) totalitarian regimes and the prohibition of propaganda of their symbolism» etc.). As S. Butko, the representative of the Ukrainian Institute of National Remembrance, mentions, one of the key provisions of this deccomunization politics is the statement that it was the agreement between Nazi Germany and the USSR of 23 August 1939 that entailed the start of World War II [23].

Such resolutions and legal acts adopted by European countries and countries that aspire to become a part of the European Union are associated with quite specific political and ideological aims oriented against Russia, while bearing no relation to real history. 
At the same time, there is not a word about the Munich Agreement of 1938 signed by England, France, Germany and Italy on the transfer of the Czechoslovakia's Sudetenland to Germany. It is also concealed that along with Germany, Poland was involved in the partition of Czechoslovakia, and in accordance with the agreement with Germany, it occupied the Cieszyn Silesia.

As evidenced by archival documents, Poland expressed “...deep gratitude for the loyal interpretation of Polish interests at the Munich conference, as well as for the sincerity of relations during the Czech conflict." It also "paid tribute to the position of the Fuehrer and Reich Chancellor" [cit. 45].

It was the Munich Agreement, not the Molotov-Ribbentrop Pact, that served as the trigger, after which, according to the President of the Russian Federation V.V. Putin, a big war in Europe became inevitable [45].

The opinion of the historian and political scientist, member of the Public Chamber of the Russian Federation N.A. Narochnitskaya seems quite fair and reasonable to the authors. Natalia Alekseevna argues that the Soviet-German non-aggression pact was demonized by Western historians, who on the other hand do not denounce Western countries for the Munich agreement and consent to the Anschluss of Austria, which became the start of Hitler's invasions and the breakdown of the territorial status quo. As for the Soviet-German non-aggression pact itself, N.A. Narochnitskaya assumes that it did not differ from standard treaties that had been concluded throughout the history of international relations. Hitler's Germany was a globally recognized state that had intensive diplomatic relations, primarily with all Western countries $[29,96]$.

By that time, the following treaties had already been concluded: an international treaty between Italy, Great Britain, Germany and France in July 1933, which assumed political cooperation aimed at elimination of the threat of war in Europe; in 1934 the NonAggression Pact between Germany and Poland (Pilsudski-Hitler Pact); in 1935 the AngloGerman Naval Agreement; in 1936 the Treaty between Germany and Japan (AntiComintern Pact), to which Manchukuo, Hungary and Spain joined in 1939; on September 30, 1938 declaration of mutual non-aggression between Great Britain and Germany; in March 1939, the non-aggression pact between Germany and Lithuania; in June 1939, the non-aggression treaties between Germany and Estonia, and Germany and Latvia, etc.

Russian President Vladimir Putin in his article "75th Anniversary of the Great Victory: Shared Responsibility to History and our Future" recalled the fact that the Soviet Union appealed to the European countries to form an equal system of collective security and, in particular, to conclude the Eastern European and Pacific Pacts, which would have protected the world from aggression [45]. Unfortunately, these proposals fell on deaf ears.

The instructions of the British military mission, which arrived in Moscow in August 1939 for negotiations, explicitly stated that the delegation should "negotiate slowly"; that "the government of the United Kingdom is not prepared to undertake detailed obligations that may limit our freedom of action under any circumstances" [cit. 45].

Professor I.M. Ilyinsky, the rector of Moscow University for the Humanities, also draws attention to the fact that Joseph Stalin tried with all his might to create an anti-Hitler coalition with Britain, France and the United States. Ilyinsky states that Joseph Stalin got to accept Hitler's proposal to conclude a non-aggression pact only after his attempts on creating anti-Hitler coalition failed, since the country was not yet ready for war [21].

Kennedy Hickman, the expert on military and naval history, director of the museum in Pennsylvania (USA) also believes that Joseph Stalin, while having observed how Western countries colluded to give Czechoslovakia to Hitler, was worried that such a situation could happen to the Soviet Union as well. Stalin started negotiations with Great Britain and France about a possible alliance. In the summer of 1939, when negotiations were 
deadlocked, the Soviets started negotiationing with Nazi Germany on the non-aggression pact. The final document, the Molotov-Ribbentrop Pact, was signed on 23 August [9].

This point of view is shared by the American professor Grover Furr. He believes that "the Soviet Union signed the non-aggression pact with Germany not to "partition Poland", like the allies partitioned Czechoslovakia (Munich Agreement of 1938 - author's note), but to defend itself" [6].

As Sergei Ivanov, the chairman of the Board of Trustees of the Russian Military Historical Society, rightly notes, if the Soviet-German treaty had not been concluded, the beginning of aggression against the Soviet Union would not have been from the borders where it happened, but much to the east. In addition, the signing of a non-aggression pact in 1939 helped the Soviet Union avoid a war on two fronts, since if this document was not signed, Japan could declare war [17].

In the days of The Munich Agreement, the US Secretary of the Interior Harold LeClair Ickes wrote in his diary: "I am not surprised by the actions of Russia ... Russia suspected that England was playing a double game, negotiating with Germany. I think that Russia is right: England could have reached an agreement with Russia long ago. England hoped aimlessly that they would be able to push Russia and Germany against each other and thus remain unharmed themselves. They were caught in the net that had been set up by themselves and, thus, lost sympathy all over the world" [cit.: 22.16].

However, historical facts, archive documents, opinions of statesmen and researchers that do not correspond to views and judgments of neoliberals are ignored or mischaracterized by them.

\subsection{The Great Patriotic War}

There was not any Great Patriotic War from neoliberals' perspective! In the opinion of Senior Research Fellow of Institute of Scientific Information on Social Sciences of the Russia Academy of Sciences (INION RAN) I.I.Glebova, so-called the Great Patriotic War as well as the victory over Nazi Germany are myths of Soviet propaganda [27]. There was war for world domination between two totalitarian regimes. Stalin was preparing to attack Hitler, but was late [39]. The fact that by having done so Hitler tried to justify the attack on the Soviet Union [41] does not cast a doubt for neoliberals. Most importantly, this corresponds to the neoliberal value judgment, according to which Stalin is the same criminal as Hitler, the Soviet regime is not less, but rather more criminal than Hitler's [42]. This approach essentially embodies one of principles of Reich Minister of Propaganda Joseph Goebbels: if you repeat a lie often enough, people will believe it.

So, the English historian, Professor Orlando Figes, is convinced that According to the most conservative estimates, about 25 million people were repressed by the Soviet regime between 1928, when Stalin seized control of the communist party leadership, and 1953, when the dictator died... These 25 million: executed by firing squads, prisoners of the gulag, «kulaks» (well-off peasants), sent to «special settlements», different-type slaves, representatives of deported nationalities - make up about one eighth of the Soviet population, which was approximately 200 million people in 1941, or on average one person for every 1.5 families in the Soviet Union» [4].

Therefore, people could not love Stalin and the Soviet state from the perspective of neoliberals. It was horrendous totalitarian regime.

On this basis, it is proposed to consider also the reasons for the Red Army's defeats in the initial period of the war. Thus, according to the Dean of the Department of Russian Studies of the Institute of Social Sciences, I.B. Chubais, since $90 \%$ of the officers' corps had been exterminated before the war broke out, no one intended to defend the regime. 
People could not wait a war to spare them from tyranny and welcomed nazis with open arms [32].

It is noteworthy that Igor Chubais is in fact referring to Adolf Hitler, who, cited his doubtful generals as the main argument to endorse the decision to attack on the USSR, that $80 \%$ of the Red Army's command and staff had been destroyed. The Red Army was haphazard and weak as never before. The war had to start until the soviets recovered their manpower [cit.: 26].

Archival data on the work of the Military Collegium of the Supreme Court of the USSR and courts martial, which are quoted by the Deputy Chairman of the Military Collegium of the Supreme Court of the Russian Federation, Major-General of Justice, A.T. Ukolov, and Lieutenant-Colonel, V.I. Ivkin, show that persons of the highest, middle and junior command and supervisory ranks, as well as of the rank and file, were tried for counterrevolutionary crimes in 1936 - 925 people, 1937 - 4,079 people, 1938 - 3,132 people, 1939 - 1,099 people and 1940 - 1,603 people. According to the archive of the Military Collegium of the Supreme Court of the USSR, 52 military men were sentenced to death penalty in 1938, 112 in 1939 and 528 in 1940. As of January 1, 1939, the strength of the Armed Forces of the USSR was 1.485 million people, and on June 22, 1941 it grew to 5.774 million people. Analysis of the judicial statistics conducted by A.T. Ukolov and V.I. Ivkin shows that the number of victims of political repression in the Red Army in the second half of the 1930 s is ten or more times lower than modern publicists and researchers cite $[18$, $57,59]$.

Journalist, political observer Y.L. Latynina, like I.B. Chubais and other neoliberals, is convinced that "... the soldiers dropped their weapons because they hated Stalin, and their flight was a real nationwide referendum. A referendum on how the Russian people really treat the bloody tyrant who took away their freedom, property and life" [20]. What happened in reality does not fit into the neoliberals' scheme and, therefore, is not considered by them. Otherwise, it would be necessary to explain who and why, in the view of neoliberals, from the first days of the war, heroically defended the Brest Fortress, Liepaja, the Hanko Peninsula, Przemysl, Mogilev, Tallinn. Why, in the reports of the Hitlerite command in the battles in the Vilnius direction it was particularly emphasized that "the enemy ... resisted fiercely and bravely, fighting to death. There were no reports of defectors or surrendered prisoners. That was why the battles were fiercer than during the Polish Campaign or the Western Campaign» [Cit. of: 38,223]. And the Chief of General Staff of the German ground forces, General F. Halder, wrote in his diary: "Information from the front confirms that Russians are fighting everywhere to the last man ..." [Cit. of: 38, 223].

From the perspective of neoliberals, it is difficult to explain the fact that 5.3 million people were mobilized in the first eight days of the war alone [35,273]. Many came to the recruiting stations on Sunday, June 22, straight after the radio had announced the attack of Nazi Germany. It was before the call for mobilization.

In this regard, it is interesting that the American researcher Geoffrey Hayes is surprised to note that even though Stalin purged the army, sent millions to the Gulag and killed millions more in the course of collectivization, he was able to inspire soldiers to make incredible sacrifices in the name of Russian patriotism. Soldiers wrote on tanks: For the Motherland! For Stalin! However, many Russians and representatives of other ethnic groups and nationalities sided with the Nazis [8].

One can agree with the opinion of the Italian historian and journalist, one of the most reputed specialists in the history of Eastern Europe, Giuseppe Boffa, who believed that in the first months of the war there were massively doubts, bitterness, confusion, fear, reaching despair, but a stubborn desire for resistance, belief that the enemy will not win prevailed. Whereas tragic losses, military failures of the initial period did not turn into a national defeat, an irreparable catastrophe [15.30-31]. 
The next important question from the history of World War II in the neoliberal perspective concerns the looting of the Soviet Army during the liberation campaign in Europe.

\subsection{Soviet Army is the army of "looters"}

Soviet dissident, President of the Human Rights Institute S.A. Kovalev believes that Soviet soldiers, brought up by "rob what was robbed" authorities, as soon as they entered the territory of East Prussia, began to plunder civilians, in fact, with the approval of the command.

The soldiers sent home monthly parcels with watches, cloth cuts, etc. The officers sent heavier parcels, and the generals sent the stuffed up with the loot train cars. This is a long history, notes Sergey Kovalev, when the city was left to plunder [33]. Neoliberals deem that a criminal state had a criminal army, what else could civilized Europe expect from it.

It is interesting that S.A. Kovalev, in fact, repeats after the British historian Max Hastings. In his book Armageddon: The Battle for Germany, 1944-1945, published in 2004, Max Hastings wrote that the lust for trophies "became epic. The existing order in the Red Army facilitated that happening, according to which every soldier could send home a parcel with trophies once a month. Everything went to the USSR: food, drinks, livestock, clothes ..." [Cit. of: 25].

The officers were allowed to send boxes. Moreover, the weight of the box was not limited. Only the size was determined [Cit. of: 23]. Generals and other high-ranking officials of the USSR let themselves loose at the end of the war and in the first months after the Victory. The situation had become so outrageous and out of control that trains with plundered trophies burst at the seams [Cit. of: 23]. An apparent conclusion offers itself - an army of looters came to poor Germany and from a soldier to a marshal robbed it of everything.

In this regard, it seems necessary, first of all, to recall what monstrous crimes committed by the Nazis the soldiers saw, liberating their homeland and fighting their way out west. As a German soldier who had been in the occupied countries for six years said: "If ... the Russians win ... and do to our people just a percent of what we have been doing with them for six years straight, then not a single German will survive in a few weeks"[19].

As the leading researcher of the Institute of Russian History of the Russian Academy of Sciences E.S. Senyavskaya notes, we need to understand the feelings of those who sent home, to their destroyed hometowns, a package of trophies allowed by the command. However, in the overwhelming majority of cases, it was not about the taken away valuables, but about abandoned and ownerless things [37].

How it was we know from the participants of those events.

For example, first sergeant V.V. Syrlitsin, in a letter to his wife in June 1945, emphasized: "We are not like the Fritzes who were in Krasnodar - no one robs or takes anything from people, but these are our legitimate trophies, taken either in Berlin stores and warehouses or found the gutted suitcases of those who made off from Berlin" [Cit. of: 40,496].

Red Army soldier N.A. Orlov recalled about the trophies: “.... I saw no impudent plunder. If a thing was taken, then only from abandoned houses and shops.

"Omniscient eye" of special agents had no rest. Sometimes they shot for looting ... Our officers took pictures, tapestries and other valuable things from mansions. When it was allowed to send parcels home, there were weight restrictions: if I'm not mistaken, an officer could send a parcel up to $8 \mathrm{~kg}$, a soldier - up to 3 kilograms. I sent my mother a parcel with cuts of fabric, and it was safely delivered. Somehow we ran into a box of German watches "stampings", with all our unit we packed them, but those parcels "disappeared". Everyone 
in the troop had a "collection" of watches and lighters, which we usually kept in helmets ... But I did not see anyone carrying gold rings in a pouch" [20].

At the same time, it should be mentioned that there were cases of "hoarding" in Soviet troops at the final stage of the war and right after its end. However, only a few strove to make profit, mainly "drivers and base area soldiers". Contemptuous statements about things - trifles, rags, rubbish, junk - were in letters and diaries very often. "There was no place for meaningless trifles when you every day confront death" $[40,496]$.

Most of the Soviet soldiers simply tried to support their families in the rear, sending things necessary in everyday life to ruined cities and villages in order to somehow compensate for the losses the war incurred or to give family the opportunity to exchange what they sent for food.

In fairness it must be said that there were cases of looting. As a former propaganda worker, later a literary critic and dissident L.Z. Kopelev, recalling the battles in East Prussia told: "I don't know the statistics: the number of scoundrels, looters, rapists that were among our soldiers. I am sure they were a tiny minority. However, it was they who made, so to speak, a lasting impression" [31,23].

It should be noted that many soldiers and officers themselves fought vigorously against looting and violence. The harsh sentences of courts martial also contributed to their suppression. According to the military prosecutor's office, "in the first months of 1945 courts martial convicted 4148 officers and a large number of privates for the atrocities committed against the local population. Several demonstrative trials of military men ended with the imposition of death sentences on the perpetrators" [36,31].

To complete the picture, let us see how things were with looting in the armies of the allies - the United States and Great Britain, countries where "independent and free, tolerant and noble people" [7,224] live, who fought in defense of "traditional liberal values" [7,224]

For example, Chief Corporal Kopiske recalled: “...At the railway crossing before the village, we were met by a "post for collecting weapons and watches". I thought I was dreaming: civilized, prosperous Englishmen are taking watches from German soldiers covered with mud! ... The British guarding us ... bragged to each other about their trophies, throwing up their hands high, geared up with wristwatches" [43,559-560].

And this is what sergeant of the Guards N.N.Nikulin wrote in his memoirs: "A huge flea market appeared at the Brandenburg Gate, where any currency was accepted and one could buy anything: a suit, a pistol, food, a woman, a car. I saw an American colonel selling watches right from the jeep, hanging them on his spread fingers ...” [30,191].

An interesting book is "The Victory's Road" by Australian war correspondent Osmar White, who was in Europe in the troops of the US 3rd Army. O. White write about the trophies: "Victory meant the right to trophies. The victors took everything they liked from the enemy: booze, cigars, cameras, binoculars, pistols, hunting rifles, decorative swords and daggers, silver jewelry, cutlery, furs. This kind of robbery was called "liberation" or "souvenir taking". Military police did not pay attention to this until the predatory liberators (usually soldiers of auxiliary units and transport workers) began to steal expensive cars, antique furniture, radios, tools and other industrial equipment and come up with cunning methods of smuggling stolen goods to the coast in order to ship it to England. Only after the combat action stopped, the military command intervened and established law and order when plunder turned into an organized criminal racketeering. Before that, soldiers took whatever they wanted, and the Germans had a hard time" [31, 36]. 


\section{Conclusion}

Whether the historical assessment can change due to the emergence of new, previously unknown (not available) sources, the appearance of which significantly changes the view of the event, then the political assessment is more volatile, it depends on the current political situation, i.e. it is opportunistic and influenced by a number of subjective factors. Such an assessment aims to tackle political short- or medium-term objectives, to favor certain questions, to shape public opinion in the current conditions, which may often be driven by emotions and slander [1].

Having considered the perspective of neoliberals on some aspects of the history of World War II, it can be concluded that the purpose of neoliberal approach in covering these issues is not to objectively analyze the events, but to declare the Soviet Union and the Red Army criminals. To support their point, neoliberals refer to biased sources, juggle the facts and tell lies. Revision of the history of World War II from this perspective is directed against modern Russia, its place, role and significance in the world. That is why diligent, meticulous work of historians is necessary as well as the publication of archival materials, the results of scientific research, conferences and other events in order to show people the real history of World War II.

As for the neoliberal agenda, calling Soviet army looters, their claims are factually wrong. Though, incidents of this kind did happen, but they were not systemic and were curbed by the military command. This also applies to the allied armies.

\section{References}

1. V. Bruz, Modern Journal of Language Teaching Methods 8(11), 825 (2018)

2. R.M. Ebeling, How Stalin Used Hitler To Start World War II, https://www.capitalismmagazine.com/2016/05/how-stalin-used-hitler-to-start-worldwar-ii/

3. European Parliament resolution of 19 September 2019 on the importance of European remembrance for the future of Europe (2019/2819(RSP)), https://www.europarl.europa.eu/doceo/document/TA-9-2019-0021_EN.html

4. Figes Orlando The Whisperers, https://www.npr.org/templates/story/story.php?storyId=17376494

5. Foreign Relations of the United States, Diplomatic Papers (Washington, 1958)

6. Furr Grover, Did the Soviet Union Invade Poland in September 1939? The answer: No, it did not..., https://www.jugashvili.com/blog/did-the-soviet-union-invade-poland-inseptember-1939-the-answer-no-it-did-not

7. F.A. Hayek, The Road to Serfdom (London and New York, 2006)

8. Hays Jeffrey, World War II and the Soviet Union, http://factsanddetails.com/russia/History/sub9_1e/entry-4971.html Kennedy Hickman, World War II: Causes of Conflict, https://www.thoughtco.com/world-war-ii-road-towar-2361456

9. Our policy stated, The New York Times, June 24 (1941)

10. Overy Richard The Soviet-German War 1941 - 1945, https://www.bbc.co.uk/history/worldwars/wwtwo/soviet_german_war_01.shtml

11. The Times, 4th September (1939) 
12. Zita Whalley, Why WWII Is Called the Great Patriotic War in Russia, https://theculturetrip.com/europe/russia/articles/why-wwii-is-called-the-great-patrioticwar-in-russia/

13. Bessmertny polk, https://www.moypolk.ru/

14. G. Boffa, Istoria Sovetskogo Soyuza (M.: Mezhdunar. Otnosheniya, 1994)

15. V.V. Bruz, Deyatel'nost' Organizatsii Varshavskogo Dogovora po obespecheniyu yevropeyskoy bezopasnosti. (Istoriograficheskoye issledovaniye). Monogr. (M, 2009)

16. V Kremle ob"yasnili pol'zu pakta Molotova - Ribbentropa, https://m.news.yandex.ru/turbo?text=https\%3A\%2F\%2Flenta.ru\%2Fnews\%2F $2019 \% 2$ F07\%2F04\%2Fwar_\%2F

17. Voyenno-istoricheskiy zhurnal 1, 57-59 (1993)

18. Voyna Germanii protiv Sovetskogo Soyuza 1941-1945. Dokumental'naya ekspozitsiya goroda Berlina k 50-letiyu so dnya napadeniya Germanii na Sovetskiy Soyuz (Berlin, 1992)

19. Iz interv'yu Orlova Nauma Aronovicha na sayte «Ya pomnyu», http://iremember.ru/memoirs/minometchiki/orlov-naum-aronovich/

20. I.M. Il'inskiy, Literaturnaya gazeta 18(6508) (2015)

21. Y. Latyninoy, Radiostantsiya «Ekho Moskvy» http://www.echo.msk.ru/programs/code/677955-echo/

22. N.K. Svanidze, Istorichesky process: Velikaya Otechestvennaya Redaktsiya portala «Pravoslavnyy mir» (2020) //http://www.pravmir.ru/istoricheskij-process-velikayaotechestvennaya-tekstvideo/\#ixzz3XrogfFRd

23. Konferentsiya u Chernihovi: «Ukrayina u Druhiy svitoviy viyni: mify i real'nist'», http://www.memory.gov.ua/news/u-chernigovi-proveli-konferentsiyu-ukraina-u-drugiisvitovii-viini-mifi-i-realnist/

24. V.M. Kulish, Istoriya vtorogo fronta v Yevrope (M., 1971)

25. Marodory-osvoboditeli. Kak sovetskiy soldat grabil Yevropu, http://crime.in.ua/statti/20150512/marodery-osvoboditeli

26. Marshal Vasilevskiy - bez repressii 1937-go ne bylo by voobshche voyny v 41-m, https://www.politforums.net/historypages/1432130132.html

27. Mezhdunarodnaya konferentsiya «Velikaya Otechestvennaya voyna - 70 let napadeniya natsistskoy Germanii na SSSR» (Budapesht, 2011) http://www.regnum.ru/news/polit/1415885.html

28. Milliony rossiyan proshli $v$ "Bessmertnom polku" po vsey strane, https://ruposters.ru/news/09-05-2019/bessmertnii-polk-2019 N.A. Narochnitskaya, Za chto is kem my voyevali (M., Minuvsheye, 2005)

29. N.N. Nikulin, Vospominaniya o voyne (SPb, 2008)

30. Ogonek 36, 23 (1989)

31. Pobeda nad blokadoi, https://history-ru.livejournal.com/201214.html

32. Polezen li dlya obshchestva patriotizm? Vremya vykhoda v efir: 13 march 2015, 20:07, http://www.echo.msk.ru/programs/year2015/1510240-echo/

33. Polku pribylo, https://rg.ru/2019/05/06/bessmertnyj-polk-projdet-v-110-stranah-i-v500-gorodah-mira.html

34. 50 let Vooruzhonnykh Sil SSSR (M., Voyenizdat, 1968)

35. O.A. Rzheshevskiy, Voyenno-istoricheskiy zhurnal 5, 31 (2003) 
36. Y. Senyavskaya, Krasnaya Armiya v Yevrope v 1945 godu. Staryye i novyye stereotipy $\begin{array}{lllll}\text { vospriyatiya Rossii } v & i & \text { na Zade, }\end{array}$ http://www.perspektivy.info/history/krasnaja_armija_v_jevrope_v_1945_godu_staryje _i_novyje_stereotipy_vosprijatija_v_rossii_i_na_zapade_2012-05-04.htm

37. P.N. Bobylov, V.P. Bokarev, S.V. Lipitskiy, M.Ye. Monin, Sovetskiye Vooruzhonnyye Sily. Voprosy i otvety. Stranitsy istorii (M., Politizdat, 1987)

38. B. Sokolov, Kak Gitler operedil Stalina i zachem nuzhno chitat' nemetskiye arkhivy, https://republic.ru/posts/67595

39. I.G. Tazhidinova, Problemy rossiyskoy istorii (M., Magnitogorsk, 2010)

40. Khronos. Vsemirnaya istoriya $v$ Internete, http://www.hrono.info/dokum/194_dok/1941nota.php

41. S. Kurtua, N. Vert, ZH.-L. Panne, Chernaya kniga kommunizma prestupleniya, terror, repressii (perevod s frantsuzskogo) (M., Izdatel'stvo «Tri veka istorii», 2001)

42. K.H.Shoyfler, V. Tike, Marsh na Berlin 1944-1945 (M., 2005)

43. A. Yakovlev, Sumerki, http://fanread.ru/book/8348536/?page=1

44. V.V. Putin, Rossiyskaya Gazeta 133(8187) (2020) 